\title{
Ellipsis in English Coordinated Clauses in the Novel Entitled 44 Scotland Street by Alexander McCall Smith
}

\author{
Kadek Sandy Wangi ${ }^{{ }^{*}}$, I Ketut Tika ${ }^{2}$, I Made Budiarsa ${ }^{3}$ \\ ${ }^{[123]}$ English Department, Faculty of Arts, Udayana University \\ ${ }^{1}$ [wangisandy@gmail.com], ${ }^{2}$ [ketut_tika@yahoo.com], ${ }^{3}$ [made_budiarsa@yahoo.com] \\ *Corresponding Author
}

\begin{abstract}
Abstrak
Judul dari skripsi strata satu ini adalah Ellipsis in English Coordinated Clauses in the Novel Entitled 44 Scotland Street by Alexander McCall Smith. Tujuan penelitian ini adalah untuk mengklasifikasikan jenis elipsis dan menganalisis posisi elipsis dalam klausa koordinasi. Data dari penelitian ini adalah dalam bentuk klausa bahasa Inggris yang dikoordinasikan dengan koordinasi dan, atau, dan tetapi yang ditemukan dalam sebuah novel berjudul 44 Scotland Street oleh Alexander McCall Smith. Data dikumpulkan dengan menggunakan metode dokumentasi yang dilakukan dengan membaca bacaan pada sumber data, mencatat, dan dilanjutkan dengan klasifikasi. Penelitian ini menggunakan teori elipsis yang ditulis oleh Quirk, dkk (1972) yang disajikan dengan menggunakan metode kualitatif dalam menganalisa data. Data yang dikumpulkan diidentifikasi sesuai dengan kategori jenis dan terjadinya elipsis dalam klausa koordinasi. Penelitian ini menggunakan metode deskriptif dalam menyajikan data. Hasil penelitian ini menunjukkan bahwa jenis elipsis koordinasi dibagi menjadi enam yaitu: elipsis subjek, elipsis kata bantu, elipsis subjek dan kata bantu, elipsis kata kerja, elipsis frase kata benda, dan elipsis pelengkap subjek. Ellipsis subjek adalah jenis elipsis yang paling sering terjadi pada data. Elipsis dapat terjadi pada bagian pertama dan klausa berikutnya dalam klausa koordinasi. Namun, elipsis dalam data sebagian besar bersifat anaforis dengan item yang direalisasikan pada urutan pertama dari serangkaian klausa.
\end{abstract}

Kata kunci: elipsis, klausa koordinasi, koordinator

\begin{abstract}
The title of this undergraduate thesis is Ellipsis in English Coordinated Clauses in the Novel Entitled 44 Scotland Street by Alexander McCall Smith. The aims of the study are to classify the types of ellipsis and to analyze the position of ellipsis in coordinated clauses. The data of this study were in the form of the English coordinated clauses with coordinating conjunction and, or, and but which were found in a novel entitled 44 Scotland Street by Alexander McCall Smith. The data were collected by using documentation method which was done by close reading on the data source, taking note, and continued by classification. This study used the theory of ellipsis proposed by Quirk, et al (1972) presented by using qualitative method in analyzing the data. The collected data were identified according to the categories of the types and the occurrence of ellipsis in coordinated clauses. This study used descriptive method in presenting the data. The result of this study shows that the types of ellipsis in coordinated are divided into six major namely: ellipsis of subject, ellipsis of auxiliary, ellipsis of subject and auxiliary, ellipsis of predication, ellipsis of head of noun phrase, and ellipsis of subject complement. Ellipsis of subject is the most frequently used type of ellipsis that occur in the data. The ellipsis can occur in the first and in the subsequent clauses in coordinated clauses. However, the
\end{abstract}


ellipsis in the data is mostly anaphoric with the realized items in the first of a series of the clauses.

\section{Keywords: ellipsis, coordinated clauses, coordinators}

\section{Background}

The information obtained from communication can be received by the listener if they do understand the speaker's point. However, when we are talking to other people in communication, we have to convey our message effectively and use a fully grammatical structure. Hence, sometimes we do not use the full grammatical structure in communication. Therefore, they do not fell tongue-tied in communication and communicative conversation can be created. People mostly discover sentences in which some elements are deleted. Indeed, they do not realize that their interpretation of the sentence is hindered by such omission. Crystal (2008: 166) stated that the element omission is a term used in grammatical analysis to refer to a part of structure which has been omitted which is recoverable from scrutiny of the context. This omission of element is known as ellipsis which is discussed and analyzed in this study.

Some difficulties often emerge since it is complex to express something in a single sentence. Furthermore, those clauses are put together in one sentence and putting the coordinating conjunction is one way that can be used to link those clauses. Sentences that are joined by the coordinating conjunction in English are called coordinated clauses and ellipsis is frequently involved in the coordination of the clauses. Therefore, it means that there is such avoiding repetition in which certain elements of the clauses are often omitted.

Ellipsis is most commonly a device that reduces redundancy. It is closely related to the sentence construction which involves its certain part in order to avoid repetition. Quirk et al. (1972: 569) claimed that ellipsis in coordinated clauses is intended to avoid repetition of the same elements of the clauses and the ellipsis can be divided into: ellipsis of subject, ellipsis of auxiliary, ellipsis of subject and auxiliary, ellipsis of predication, ellipsis of head of noun phrase and ellipsis of prepositional phrase. Indeed, a sentence with ellipsis is acceptable only if the same sentence is acceptable after 'the deleted' words are restored.

Ellipsis in coordinated clauses is an interesting phenomenon to be discussed because there is often repetition when we link one or two clauses using coordinate conjunction (and, or, and but).

Beside the repetition, sometimes there is also ambiguity in determining elements of the clauses that can be deleted when we combine two or more clauses. In order to avoid the repetition and the ambiguity, it is important to know the rules of ellipsis, particularly the ellipsis which occur in coordinated clause. Therefore, this study focuses on ellipsis in coordinated clause using the coordinators and, or, and but. The data were taken from a novel entitled 44 Scotland Street by Alexander McCall Smith.

\section{Problems of the Study}

a) What types of ellipsis are found in coordinated clauses in the novel 44 Scotland Street by Alexander McCall Smith?

b) In what positions is the occurrence of ellipsis in coordinated clauses found in the novel 44 Scotland Street by Alexander McCall Smith, 
whether in the first or in the subsequent clauses?

\section{Aims of the Study}

a) To classify the types of ellipsis in coordinated clauses in the novel 44 Scotland Street by Alexander McCall Smith.

b) To analyze the occurrences of the ellipsis in coordinated clauses whether in the first or in the subsequent clauses in the novel 44 Scotland Street by Alexander McCall Smith.

\section{Research Method}

Research method is a particular way of doing research and it is very important for the researcher to answer the problems and find the solution to something. It will be necessary to follow scientific procedures in order to reach the success in conducting research, that is, research method. The steps of the research method guide the researcher to find the answer through data source, method and technique of collecting data, method and technique of analyzing data, and method and technique of presenting data.

\subsection{Data Source}

The data in this study were taken from the novel 44 Scotland Street. This novel was published in Great Britain and written by Alexander McCall Smith. The reason for choosing this novel is that there are many phenomena of ellipsis occuring in this novel. Furthermore, that novel is very well known and the best seller novel in the world which represents the data presented in the analysis because there would be a large number of data and it would not be efficient if all the sentences were presented.

\subsection{Method and Technique of Collecting Data}

The method of collecting data used in this study was documentation method. There are some steps in collecting the data. They are: the first step started by finding the conversation between the main characters and supporting characters required for the relevant data source. The data used in this study is the novel entitled 44 Scotland Street by Alexander McCall Smith. After finding the conversation, the step was continued by finding the conversation which contained coordinated clauses. Every chapter of the novel became the object analysis. The appearance of usage of any kinds of ellipsis in coordinated clauses being searched by finding the conversation in every chapter carefully in order to find the details and the accurate data. The next step continued by underlining and taking a note. After finding out the matters, the process of collecting data continued by identification because it is important in relation to collect the data which is appropriate to be required as the analysis in this study.

\subsection{Method and Technique of Analyzing Data}

The data were analyzed using the qualitative method because the data for the current study belongs to qualitative data which was based predominantly on non-numerical data. Indeed the main analysis of this study is concerned with answering the problems which are described clearly as follows: firstly, the collected data were identified according to the categories of the types of ellipsis in coordinated clauses using the theory of ellipsis proposed by Quirk, et al (1972). Identification of the data in this study was important to collect the data which 
were appropriate to be required as the data analysis in the current study. Then, it was continued by classifying the data into what kind of ellipsis they belong to. And finally, the sentences containing the omission or ellipsis in coordinated clauses were analyzed using the theory of ellipsis proposed by Quirk, et al (1972) in order to answer the second question about the occurrence of the ellipsis in coordinated clauses. Moreover, in analyzing the types of ellipsis, the elliptical element was shown by using bracket system and described by identifying them.

\subsection{Method and Technique of Presenting the Result of Data Analysis}

This study used descriptive method in presenting the data. The collected data were sorted from the original novel. The sorted data were divided based on the types and the occurrence of ellipsis. The data were presented by explaining and describing them in words or sentences through the steps as follows: first, the collected data were classified into several types of ellipsis and the occurrences of ellipsis. The original data were put in the elliptical form, and then the analyzed data were shown in a complete form. Furthermore, in analyzing the types of ellipsis, the elliptical items were shown using bracket system. Finally, the analyzed data were presented in the form of paragraph before the elliptical and the complete form were shown.

\section{Result and Discussion}

5.1 Analysis of Types of Ellipsis in English Coordinated Clauses

\subsubsection{Data 1}

Matthew : "Where would we get all these paintings from?"

Pat : "You had contacted an artist and you asked him to give you whole lot of paintings. Artist like that. It's a show"

Matthew : "I don't know any artists."

Pat : "I know some artists and have been seeing them. We had an artist in residence at school. He's very good." (P.109)

The conversation above tells that Matthew did not know a few things about the paintings and the artists even though he is the owner of an art gallery. Pat thought that Matthew's behavior that he very quickly became bored with what he was doing. Furthermore, Matthew thought that the gallery did virtually no business. Therefore, Pat suggested Matthew to hold an exhibition in order to make the gallery known by people.

Matthew : "Where would we get all these paintings from?"

Pat : "You had contacted an artist and you asked him to

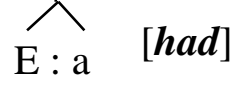

give you whole lot of paintings. Artist like that. It's a show"

Matthew : "I don't know any artists."

Pat : "I know some artists and $\lambda^{\text {have been seeing them. }}$

$\mathrm{E}: \mathrm{s}$ $[\boldsymbol{I}\rceil$

We had an artist in residence at school. He's very good."

$\mathrm{E}: \mathrm{a}=$ ellipsis $:$ auxiliary

$\mathrm{E}: \mathrm{s}=$ ellipsis $:$ subject

The data above indicates that the sentence said by Pat occurs with the ellipsis of auxiliary. If the subjects of coordinated clauses are different, there may be ellipsis of an identical auxiliary. The elliptical auxiliary which in this case 
is had can be only ellipted in the second clause when they are identical with the first. The ellipsis of the only auxiliary is allowed because the subject of the conjoined clauses are the same which in this analyis the subject in the first and second clause is you.

Furthermore, the subject I which was said by Pat in the first clause is identical with the subject in the second clause. The use of the pro-form I said by Pat in the first clause is used to realize the item in the first clause and avoid the repetition of the subject. Therefore, the subject $\mathbf{I}$ is deleted in the second clause and indicates that the sentence occurs with the ellipsis of the subject. Both those sentences are linked by the conjunction and which is used to denote relation between the content of clauses. The elliptical forms are shown below:

1. "You had contacted an artist and you [...] asked him to give you whole lot of paintings."

2. "I know some artists and [...] have been seeing them."

The complete forms:

1. "You had contacted an artist and you [had] asked him to give you whole lot of paintings."

2. "I know some artists and [I] have been seeing them."

The complete form of the conversation which is filled with the deleted item of the sentences in the data (1) is shown below:

Matthew : "Where would we get all these paintings from?"

Pat : "You had contacted an artist and you [had] asked him to give you whole lot of paintings. Artist like that. It's a show"
Matthew : "I don't know any artists."

Pat : "I know some artists and [I] have been seeing them. We had an artist in residence at school. He's very good."

\subsubsection{Data 2}

Pat "It must be frustrating for : $\quad$ you."

Policeman : "Not really. You get used to it. I'm offsky this afternoon. My wife and I bought a bed-andbreakfast in Prestonpans. That's us fixed up."

Pat : "Will anybody want to stay in Prestonpans?"

Policeman : "It gets visitors." (P.81)

The conversation above tells that the policeman was talking about his life during he became a policeman to Pat. He have encountered everything such as horrible things, sad things, and the time in the Arts Squad which was aesthetically disturbing things.

Pat : "It must be frustrating for you."

Policeman : "Not really. You get used to it. I'm offsky this afternoon.

My wife and I bought a

$$
\begin{array}{ll}
\text { E : w.p } & {[\text { bought a }} \\
& \text { bed-and- } \\
& \text { breakfast in } \\
& \text { Prestonpans] }
\end{array}
$$

bed-and- breakfast in Prestonpans. That's us fixed up."

Pat : "Will anybody want to stay in Prestonpans?"

Policeman : "It gets visitors." 
E $:$ w.p $=$ ellipsis $:$ whole of predication

Data (2) indicates that the sentence which was said by the Policeman occurs with the ellipsis of the whole predication. The ellipsis of the whole predication bought a bed-andbreakfast in Prestonpans takes place in the first clause with the realized item is in the last clause only. That elliptical element is in the fourth sentence which was said by Policeman and it is linked by the conjunction and. The elliptical form of the sentence is discussed below:

"My wife [...] and I bought a bedand-breakfast in Prestonpans."

The complete form:

"My wife [bought a bed-andbreakfast in Prestonpans] and I bought a bed-and-breakfast in Prestonpans."

Therefore, the complete conversation of data (2) is as follows:

Pat "It must be frustrating for : you."

Policeman : "Not really. You get used to it. I'm offsky this afternoon. My wife [bought a bed-andbreakfast in Prestonpans] and I bought a bed-andbreakfast in Prestonpans. That's us fixed up."

Pat : "Will anybody want to stay in Prestonpans?"

Policeman : "It gets visitors."

5.2 Analysis of the Occurrences of Ellipsis in English Coordinated Clauses in the Novel Entitled 44 Scotland Street by Alexander McCall Smith

\subsubsection{Data 3}

Pat : "I was encouraged, but not pushed."
Domenica : "There's a big difference. I could tell that you weren't pushed. You're calm or sensible. You seem to be a very balanced person to me. You're on your way to work?"

Pat : "Yes."

Domenica : "I could give you a lift. My car is right there in the street. It would be no trouble."

Pat : "Work is just round the corner. It's kind of you though." (P.40)

The conversation above tells that when Pat left the flat in the morning to work at precisely the time that Domenica opened her door onto their mutual landing. They were talking to their neighbors, Bartie because Domenica always heard the saxophone sound. And she also offered her car to Pat to work as a new kind of neighbor.

Pat : "I was encouraged, but not pushed."

Domenica : "There's a big difference. I could tell that you weren't pushed. You're calm or $\widehat{\text { Eou're }]}^{\text {sensible. You seem to }}$ be a very balanced person to me. You're on your way to work?"

Pat : "Yes."

Domenica : "I could give you a lift. My car is right there in the street. It would be no trouble."

Pat : "Work is just round the corner. It's kind of you though."

$\mathrm{E}:$ ana $=$ ellipsis $:$ anaphoric

Data (3) indicates that ellipsis is anaphoric with the realized item which 
occurs in the clauses subsequent to the first. The subject you and the verb are which were said by Domenica in the third sentence are deleted in the second clause with the realized item in the first clause. The subject you can be deleted since they are identical with the first. This sentence is linked by the conjunction or which is used to combinr clauses which denote an alternative. The elliptical form of the sentence which was said by Domenica is shown below:

$$
\text { "You're calm or [...] sensible." }
$$

The complete form:

$$
\begin{aligned}
& \text { "You're calm or [you're] } \\
& \text { sensible." }
\end{aligned}
$$

The complete conversation of data (3) will shown below:

Pat : "I was encouraged, but not pushed."

Domenica: "There's a big difference. I could tell that you weren't pushed. You're calm or [you're] sensible. You seem to be a very balanced person to me. You're on your way to work?"

Pat : "Yes."

Domenica : "I could give you a lift. My car is right there in the street. It would be no trouble."

Pat : "Work is just round the corner. It's kind of you though."

\subsubsection{Data 4}

Matthew : 'I can't do that. He'd laugh at me. He'd tell everybody else that I don't know what I have. No, we need to get somebody else to do it. Is that all right for you? Do it tomorrow?"

Pat : "I suppose so. But I did not feel easy in the company of
Ronnie and Pete. There was something unsettling about them." (P.192)

The conversation of data (4) tells that Pat feels uncomfortable if she will be in the company of Ronnie and Pete. She feels that there was something unsettling about them. The same thing happens to Matthew, he feels clumsy because of Pete had laughed at him.

Matthew : "I can't do that. He'd laugh at me. He'd tell everybody else that I don't know what I have. No, we need to get somebody

else to do it. Is that all right for you? Do it tomorrow?"

Pat "I suppose so. But I did not feel easy in the company of Ronnie and Pete. There

E : cata

I I did not feel easy in the company of $]$

was something unsettling about them."

$\mathrm{E}:$ cata $=$ ellipsis $:$ cataphoric

Data (4) indicates that ellipsis is usually anaphoric, but it can be cataphoric when the ellipsis occurs in the first clause and it is called the cataphoric ellipsis. The elliptical item I did not feel easy in the company of takes place in the first clause with the realized item in the last clause only. This sentence is linked with the conjunction and. The elliptical form which was said by Pat is shown below:

"But I did not feel easy in the company of Ronnie and [...] Pete."

The complete form:

"But I did not feel easy in the company of Ronnie and [I did not 


\section{feel easy in the company of]} Pete."

Therefore, the complete conversation of data (4) is as follows:

Matthew 'I can't do that. He'd laugh at me. He'd tell everybody else that I don't know what I have. No, we need to get somebody

else to do it. Is that all right for you? Do it tomorrow?"

Pat "I suppose so. But I did not feel easy in the company of Ronnie and [I did not feel easy in the company of] Pete. There was something unsettling about them."

\section{Conclusion}

Based on the data been discussed and analyzed, there were several points that can be concluded. They are as follows:

a. There are six major types of ellipsis found in the novel 44 Scotland Street by Alexander McCall Smith. All of those types are ellipsis of subject, ellipsis of auxiliary, ellipsis of subject and auxiliary, ellipsis of lexical verb, ellipsis of verb including auxiliary, ellipsis of verb and subject complement, ellipsis of verb and object, ellipsis of whole predication, ellipsis of subject complement or direct object, ellipsis of adverbial, ellipsis of head of noun phrase, and ellipsis of complement of prepositional phrase. The result of this study indicates that ellipsis of subject is the most frequently used type of ellipsis that occurred in the data.

b. The ellipsis can occur in the first and in the subsequent clauses in coordinated clauses. Ellipsis can be simple or complex. The ellipsis occurs in only one of the conjoined clauses or identical items are deketed in two or more conjoined clauses found in the simple ellipsis. Meanwhile, the elliptical elements are both anaphoric and cataphoric in the same sentence found in the complex ellipsis. Ellipsis can be anaphoric with the realized items in the first of series of clauses, cataphoric with the realized items in the last of a series of clauses or both anaphoric and cataphoric. However, the ellipsis in the data is mostly anaphoric with the realized items in the first of a series of the clauses.

\section{References}

Crystal, David. (2008). A Dictionary of Linguistic and Phonetics. Blackwell Publishing, Basil.

Quirk, Randolph, et al. (1972). A Grammar of Contemporery English. Longman, London.

Quirk, Randolph, et al. (1973). A University Grammar of English. Longman Group Limited, London.

Quirk, Randolph, et al. (1985). A Comprehensive Grammar of the English Language. Longman Group Limited, London.

Smith, Alexander McCall. (2005). 44 Scotland Street. Polygon, Great Britain. 